\title{
Fecal DNA methylation markers for detecting stages of colorectal cancer and its precursors: a systematic review
}

\author{
Janhavi R. Raut ${ }^{1,2}$, Zhong Guan ${ }^{2,3}$, Petra Schrotz-King ${ }^{1}$ and Hermann Brenner ${ }^{1,3,4^{*}}$ (D)
}

\begin{abstract}
Background: DNA methylation biomarkers in stool may have applications in early colorectal cancer (CRC) detection; however, their association with stages of CRC carcinogenesis or their performance in detecting various stages is unclear. We aimed to systematically review the evidence for DNA methylation markers in stool for risk stratification or detection of specific CRC stages, as well as precursors of CRC.

Methods: We conducted a systematic search in line with the Preferred Reporting Items for Systematic Reviews and Meta-Analyses guidelines. We searched PubMed and ISI Web of Knowledge to identify relevant studies published until 14th January 2020. Two reviewers independently extracted data on study population characteristics, candidate genes, methylation measurement methods, odds ratios (ORs), overall and stage-specific sensitivities, specificities, areas under the receiver operating characteristics curve, and $p$-values for statistical significance for $\mathrm{OR}$ and for association of methylation levels with stage.
\end{abstract}

Results: Twenty-seven studies that reported stage-specific associations or performances of fecal DNA methylation markers for detecting colorectal neoplasms were identified. All studies used methylation-specific polymerase chain reaction for assessing methylation levels in the promoter or exon 1 regions of targeted genes. However, most studies were underpowered and limited by their case-control design. Furthermore, the stage-specific associations or sensitivities were validated for two markers (hypermethylation of GATA4 and VIM) only.

Conclusion: Methylation markers in stool may be useful for detection of CRC precursors or CRC staging, but promising candidate markers need to be validated in longitudinal studies on large screening populations, performing epigenome-wide analyses. Identification of stage-specific DNA methylation biomarkers in stool could boost current strategies towards early detection and enable different approaches to precision medicine for CRC.

Keywords: Colorectal cancer, Colorectal adenoma, CRC stage, DNA methylation, Stool, Odds ratio, Risk stratification, Screening biomarker, Stage-specific

\footnotetext{
* Correspondence: h.brenner@dkfz-heidelberg.de

'Division of Preventive Oncology, German Cancer Research Center (DKFZ)

and National Center for Tumor Diseases (NCT), Heidelberg, Germany

${ }^{3}$ Division of Clinical Epidemiology and Aging Research, German Cancer

Research Center (DKFZ), Heidelberg, Germany

Full list of author information is available at the end of the article
}

C C The Author(s). 2020 Open Access This article is licensed under a Creative Commons Attribution 4.0 International License, which permits use, sharing, adaptation, distribution and reproduction in any medium or format, as long as you give appropriate credit to the original author(s) and the source, provide a link to the Creative Commons licence, and indicate if changes were made. The images or other third party material in this article are included in the article's Creative Commons licence, unless indicated otherwise in a credit line to the material. If material is not included in the article's Creative Commons licence and your intended use is not permitted by statutory regulation or exceeds the permitted use, you will need to obtain permission directly from the copyright holder. To view a copy of this licence, visit http://creativecommons.org/licenses/by/4.0/ The Creative Commons Public Domain Dedication waiver (http://creativecommons.org/publicdomain/zero/1.0/) applies to the data made available in this article, unless otherwise stated in a credit line to the data. 


\section{Introduction}

Worldwide, colorectal cancer (CRC) is the third most common incident cancer and the second leading cause of cancer mortality, accounting for 1.85 million incident cases and $~ 880,000$ deaths in 2018 [1]. The disease burden can be decreased with population-based screening, which allows detection of CRC at earlier stages, when chances of cure are substantially higher than at later stages or by detection and removal of precancerous lesions [2-4]. Currently, colonoscopy is the most accurate screening method for early diagnosis of CRC. However, its compliance rate remains very low due to its invasiveness, dietary restriction requirement, and costs [5-7]. While fecal immunochemical test for hemoglobin has been proven to be an effective, currently available noninvasive test to screen patients who are at average risk for the development of CRC, it has limited sensitivity to detect advanced colorectal adenomas (AAs) or stage I CRCs $[8,9]$. Thus, effective non-invasive biomarkers that detect early stage CRC and its precursors more reliably are highly desirable.

CRC develops through a multistep process that involves accumulation of both genetic and epigenetic alterations of the cellular genome [10-12]. Among epigenetic modifications, DNA methylation is a common, early, and stable event in tumorigenesis that is easily detectable in small amounts of DNA [13]. Aberrant methylation of an increasing number of genes has been associated with the tumorigenesis of CRC [14-17]. Approval of Cologuard (multi-target stool DNA test that examines KRAS mutation, NDRG4 and BMP3 methylations, $\beta$-actin, plus a hemoglobin immunoassay) [18] and Epi proColon (blood-based test that examines SEPT9 methylation) [14, 19, 20] by the Food and Drug Administration has further confirmed DNA methylation as an applicable biomarker for CRC screening. Assessing methylation of DNA isolated from stool samples is a biologically rational approach for CRC screening since neoplastic cells are exfoliated into the colonic lumen and are mixed with stool [21, 22]. Several studies have investigated hypermethylation of the cytosine-phosphate-guanine (CpG) islands in gene promoters in stool samples as potential biomarkers for CRC screening [23-28]. In order to facilitate early detection, there is a need to understand the role of aberrant methylation events in each of the stages of colorectal carcinogenesis from non-advanced colorectal adenomas (NAAs) to AAs and then to CRC stages IIV [29]. However, a comprehensive overview of the associations of these markers with the well-established stages of CRC carcinogenesis or their performance in detecting various stages, specifically early curable colorectal adenomas (Ads), stage I or stage A and stage II or stage B CRC is lacking. The aim of this systematic review is to synthesize results from studies evaluating DNA methylation markers in stool for detecting specific CRC stages, as well as precursors of CRC.

\section{Materials and methods}

We followed the Preferred Reporting Items for Systematic Reviews and Meta-Analyses guidelines [30]; the checklist is shown in Table S1 (see Additional file 1).

\section{Eligibility criteria}

Studies were eligible for inclusion in this systematic review if they met the following inclusion criteria: examining DNA methylation in stool samples from CRC patients at various stages (including at least stage I or II) compared to healthy individuals. Our search was restricted to human research studies in English language. The first step in the selection of eligible studies was based on reading the title and abstract. Articles were excluded if they were (1) not relevant to the topic, (2) not original articles, (3) not based on stool samples, or (4) not assessing methylation markers separately but in combination with genetic markers or immunoassays. Then, the full texts of the remaining articles were read and included when deemed relevant. Finally, studies that did not report stratified results by stage or enough data to calculate them were also excluded.

\section{Information sources and search strategy}

Databases of PubMed and ISI Web of Science were searched for relevant articles until 14th January 2020. Search terms included (colorectal OR colon OR colonic OR rectal OR rectum) AND (cancer OR carcinoma OR adenoma OR neoplasm OR tumor OR malignancy OR serrated OR "sessile serrated") AND (stool OR fecal OR feces OR faecal OR feacal) AND ("cell-free DNA" OR "cell free DNA" OR "circulating DNA" OR "circulating tumor DNA" OR cfDNA OR cirDNA OR ctDNA OR DNA OR "deoxyribonucleic acid" OR ds-DNA) AND (methylation OR hypermethylation OR hypomethylation) AND (detection OR diagnosis OR screen OR screening OR marker OR biomarker). Additionally, reference lists of relevant studies and reviews were scanned to identify relevant articles. Duplicated hits were removed.

\section{Data extraction and quality assessment}

Two authors (JRR and ZG) independently extracted data from the eligible studies. Extracted variables included first author, publication year, study population (country, numbers of cases and controls, age, and cancer stage distribution), study design, targeted genetic region, DNA methylation assay, and performance in detecting colorectal neoplasms. Data on the following performancerelated indicators were extracted: odds ratios (ORs) with 95\% confidence intervals (CIs), overall and stage-specific sensitivities, specificity, areas under the receiver 
operating characteristics curve (AUCs), and $p$-values for statistical significance for $\mathrm{OR}$ and for association of methylation with stage. For articles not reporting the measures explicitly, information was extracted from available text and tables to calculate the crude ORs and sensitivities, specificity, and $p$-value for association of methylation level with stage. Discrepancies were discussed and resolved by consensus among the authors.

The quality of included articles was assessed using the QUADAS-2 (Quality Assessment of Diagnostic Accuracy Studies 2) tool [31]. The tool was tailored to the review topic, and the risk of bias and concerns regarding applicability for each study were assessed over four domains: patient selection, index test, reference standard, and flow and timing. The risk of bias and concerns regarding applicability for each study were rated as "High," "Low," or "Unclear." QUADAS-2 assessment was conducted utilizing the Review Manager software, version 5.3 (Copenhagen: The Nordic Cochrane Centre, The Cochrane Collaboration, 2014).

\section{Results}

\section{Literature search result}

The literature search and selection process are shown in Fig. 1. After removing duplicates, 278 articles were identified. On inspection of titles and abstracts, 221 articles were excluded as they were either not relevant or nonoriginal or not evaluating fecal samples. We selected 57 articles for full-text assessment. Of these, two articles were excluded because they evaluated methylation markers in combination with other markers and 28 because they did not report any stage-specific measure of performance or measure of association and did not provide enough data to calculate them. Cross-referencing did not result in identification of any additional studies. Finally, twenty-seven studies met our inclusion criteria and were included in this review. Information on ORs could be extracted or calculated for all studies except one study [32], where it was not possible to calculate the ORs due to lack of information on methylation levels among controls. Overall and stage-specific sensitivities and specificity could be extracted or calculated for all studies. AUCs were reported only in six studies.

\section{Study characteristics}

An overview on the study characteristics is shown in Table S2 (see Additional file 1). The majority of studies were conducted in Asian populations (twenty studies), including thirteen studies from China, five from South Korea, and one each from Japan and Iran. All studies followed a case-control design and collected stool samples from cases at the time of diagnosis or shortly after diagnosis. Only two studies [33, 34] explicitly reported including cases selected in a true screening setting by using samples from patients who underwent colonoscopy for CRC screening. Fifteen studies included Ads, among which six studies included both NAAs and AAs as separate groups, one study included NAAs (but no AAs), and eight studies included AAs (but no NAAs). With regard to CRC stages, six studies investigated all four stages individually, two studies investigated stages I-III individually, one study each investigated stages I-II and stage II-III individually, two studies investigated exclusively stage I, and fifteen studies investigated early (TNM I-II) and late (TNM III-IV) stages. Most of the studies selected controls as participants who were confirmed to have normal findings by colonoscopy, endoscopy, or histology. However, in one study [35] not all controls were verified with colonoscopy. In another study [36], healthy adult volunteers were selected as controls, but it was not reported if they were verified with colonoscopy. Numbers of NAAs ranged from 17 to 41, AAs from 5 to 122, CRCs from 18 to 242, and controls from 16 to 245. Stage-specific numbers of CRC were small in most of the studies. Twelve studies reported the average age and three studies reported the median age. Most of these studies reported a fairly similar age distribution between cases and controls, but a major age difference between cases and controls (52 versus 71 years) was reported in one study [37]. To measure methylation, all studies used methylation-specific polymerase chain reaction (MSP), including nine studies using quantitative methylation-specific real-time polymerase chain reaction (qMSP) and three studies using nested MSP. One study [38] used methylation-specific reverse hybridization assay (MSRH), with MethyLight serving as a reference method. The majority of the studies did not use a validation set to confirm their results. Only four studies [24, $37,39,40]$ performed independent validation of results for some markers to detect CRC, and only two studies $[37,39]$ validated the stage-specific results in independent populations.

\section{Overview of fecal DNA methylation markers evaluated for detecting different stages of CRC and its precursors}

All studies applied a gene-specific approach and evaluated the methylation status of 25 genes in association with different stages of CRC and its precursors (Table 1). Among these 25 genes, the association of hypermethylation in COL4A1, COL4A2, GATA4, ITGA4, OSMR, $T L X 2$, and VIM with CRC risk was further confirmed in independent series of samples from the same studies [24, 37, 39, 40]. Methylation of 12 out of the 25 genes was reported $\geq 2$ times and that of the remaining genes was reported only once. Most identified markers were evaluated only individually; eight markers were evaluated only in a panel, and eight markers were evaluated both individually and in a panel. SFRP2 methylation was assessed most frequently (ten times), followed by VIM 


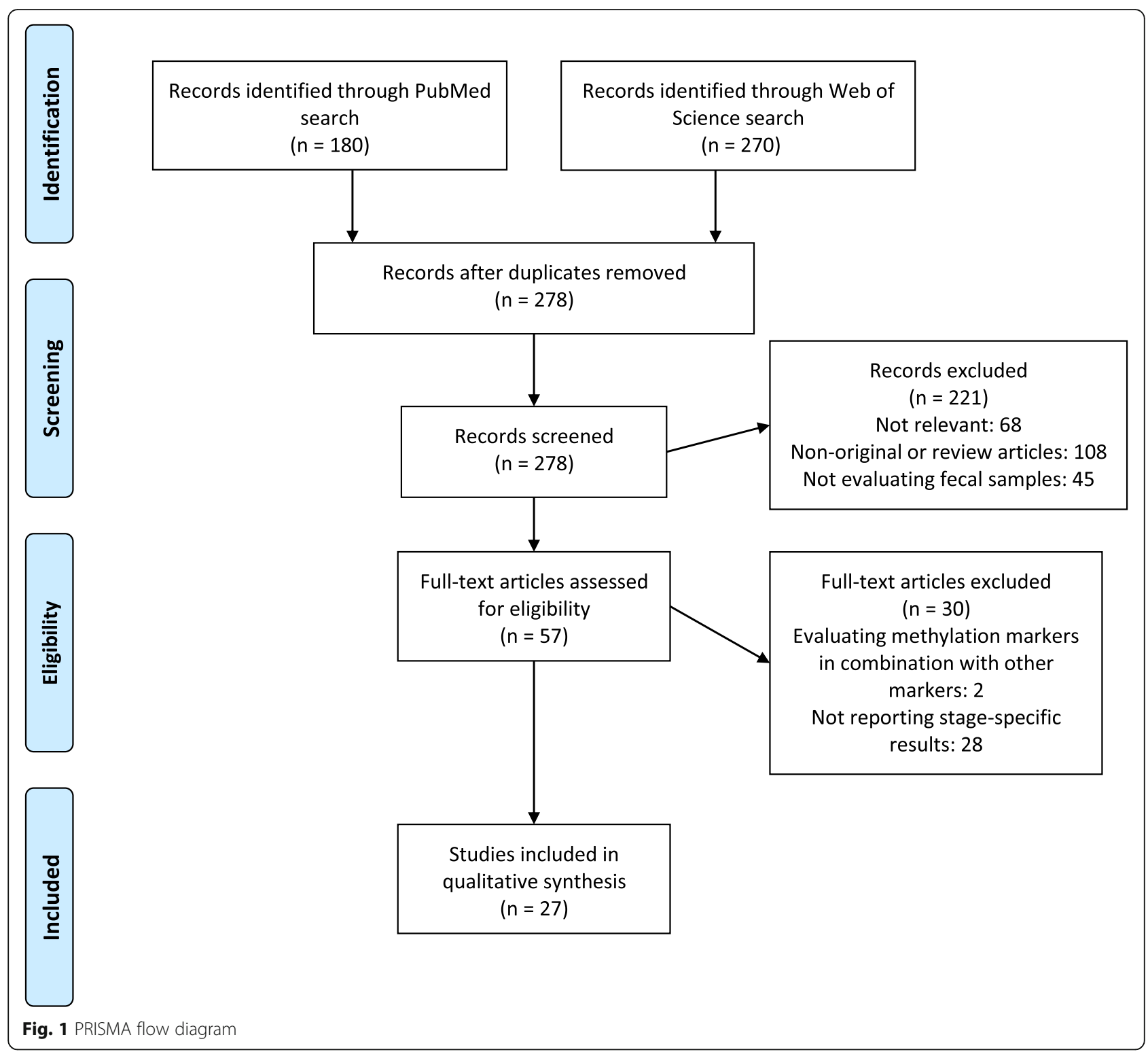

(five times), and NDRG4 (four times). The frequency of statistically significant findings for each marker evaluated individually or in a panel ranged from 75 to $100 \%$. All markers were hypermethylated among cases compared to controls. Table S2 (see Additional file 1) presents the targeted genetic region of all markers. Most of the studies assessed methylation levels in the promoter or exon 1 regions of targeted genes.

\section{Overall and stage-wise associations of individual fecal DNA methylation markers with risk of colorectal neoplasms}

Twenty-four studies evaluated individual markers, four $[24,37,39,40]$ of which confirmed the findings in independent cohorts (Table 2). The associations of markers with colorectal neoplasms could be evaluated in 23 studies using dichotomized methylation levels quantified by MSP. Only one study [38] used MSRH, with MethyLight serving as a reference method.

Four markers (SDC2, SFRP2, SFRP2: Region 1, WIF1) presented statistically significant associations with NAA, with ORs ranging from 3.0 to $41.5[28,45,50]$. Sixteen markers presented statistically significant associations with AA, with ORs ranging from 6.2 to 89.2. For overall adenomas, i.e., a combined group including NAAs and AAs, five markers presented statistically significant associations with ORs ranging from 4.3 to 64.5 [28, 45, 50, 52]. For CRC, 25 markers presented statistically significant positive associations with ORs ranging from 11.0 to 1097.2. In a study by Liu et al. [40], hypermethylation of four candidate genes, namely COL4A1, COL4A2, ITGA4, and TLX2 was associated with greater 


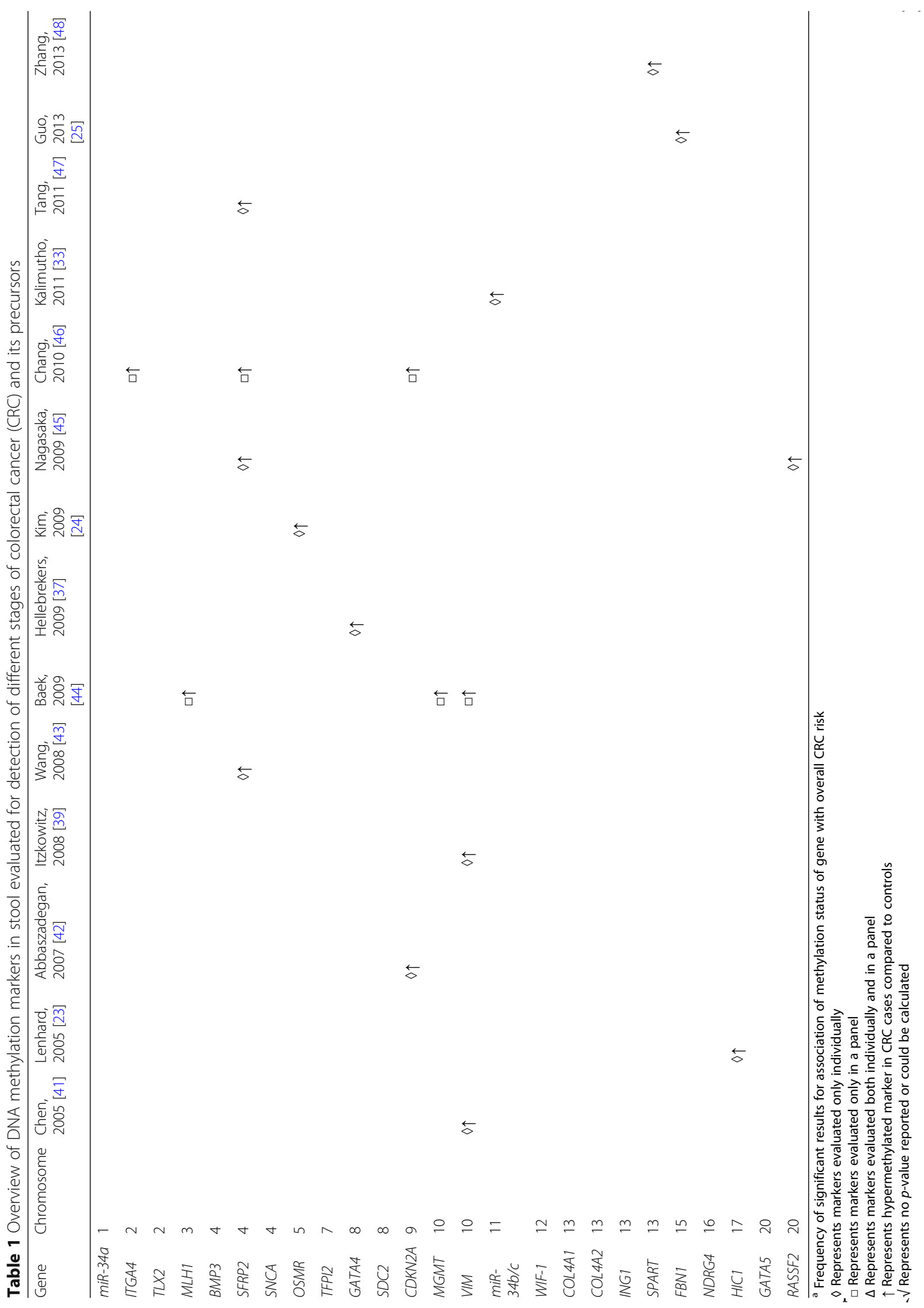




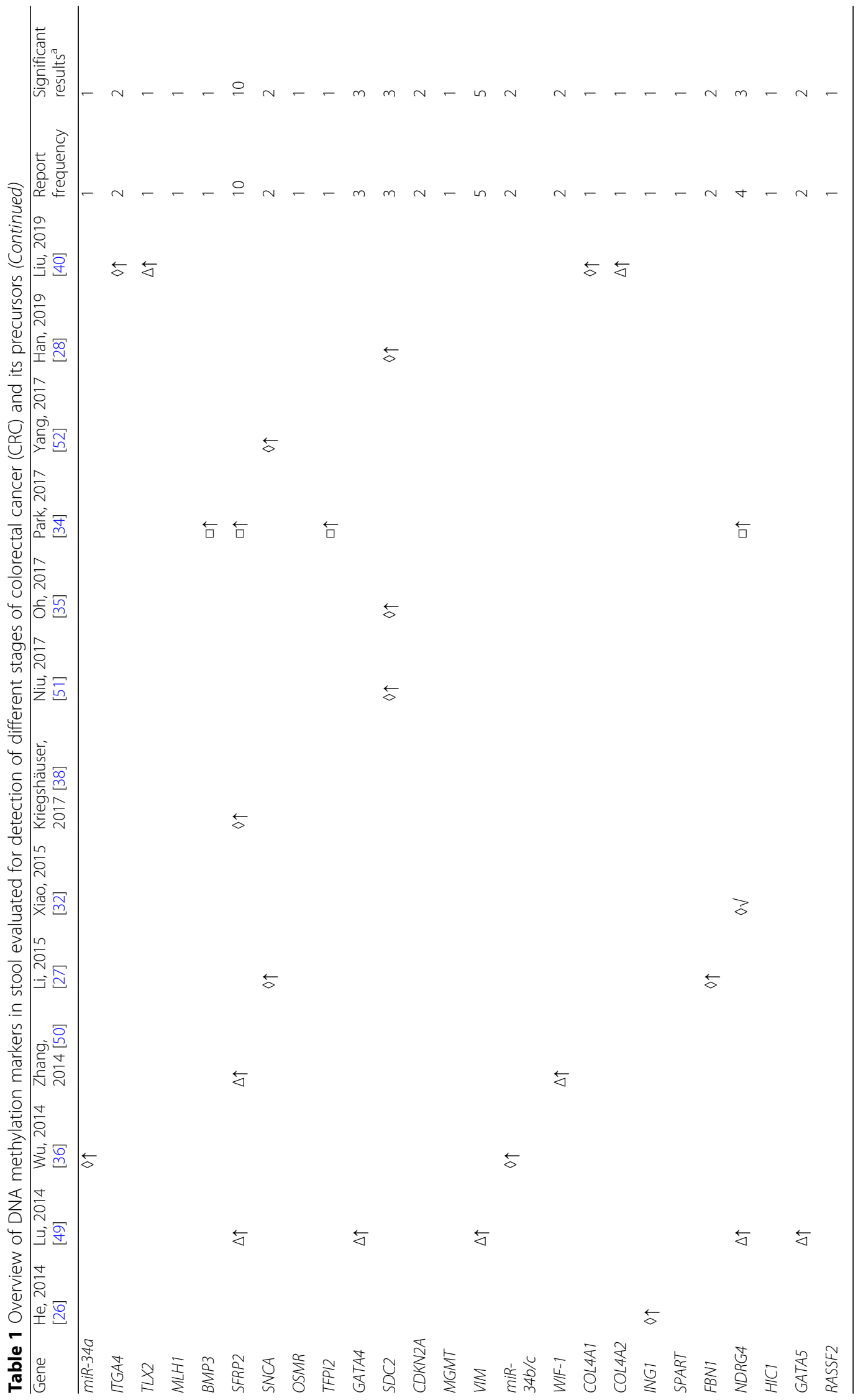




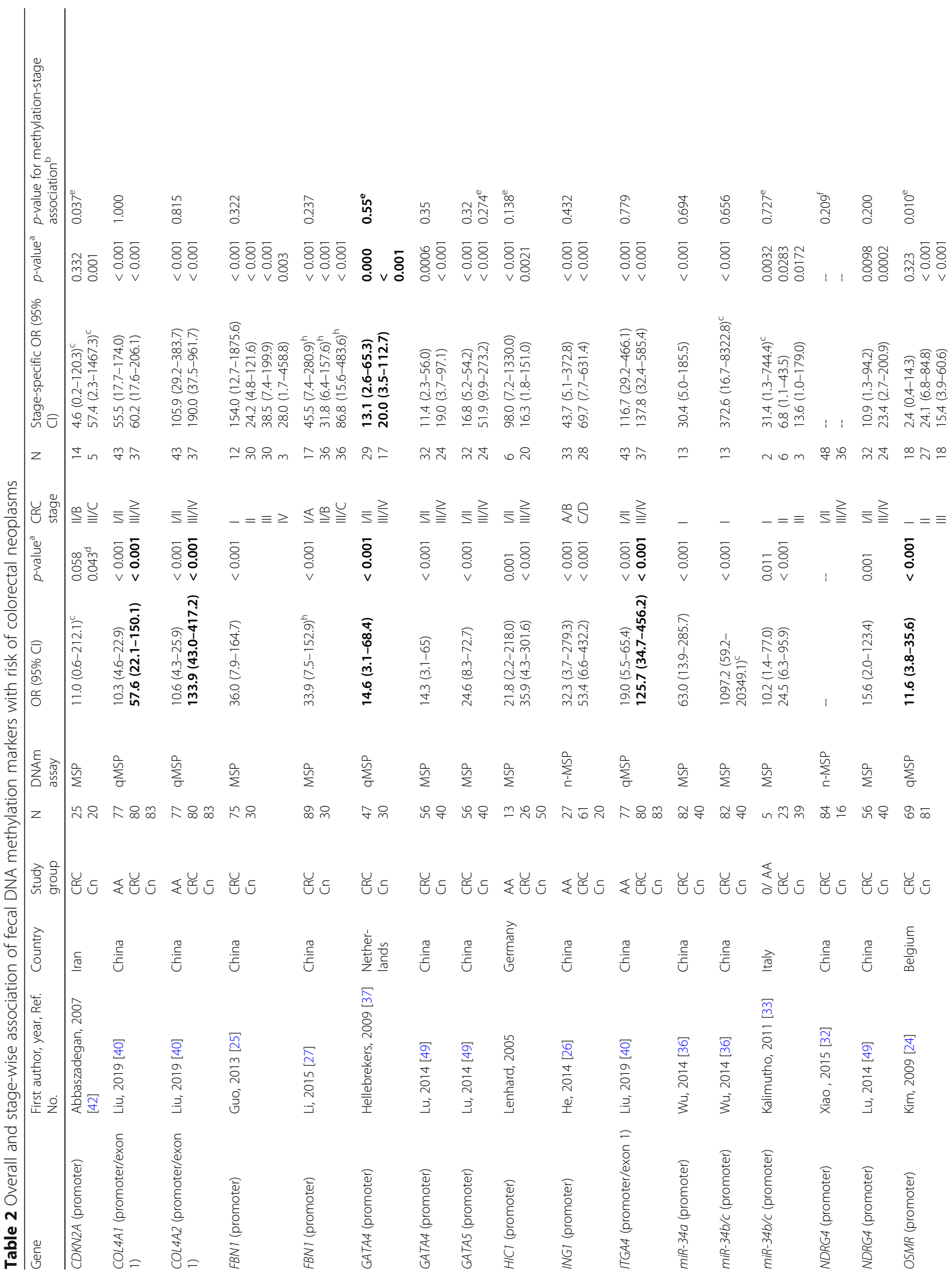




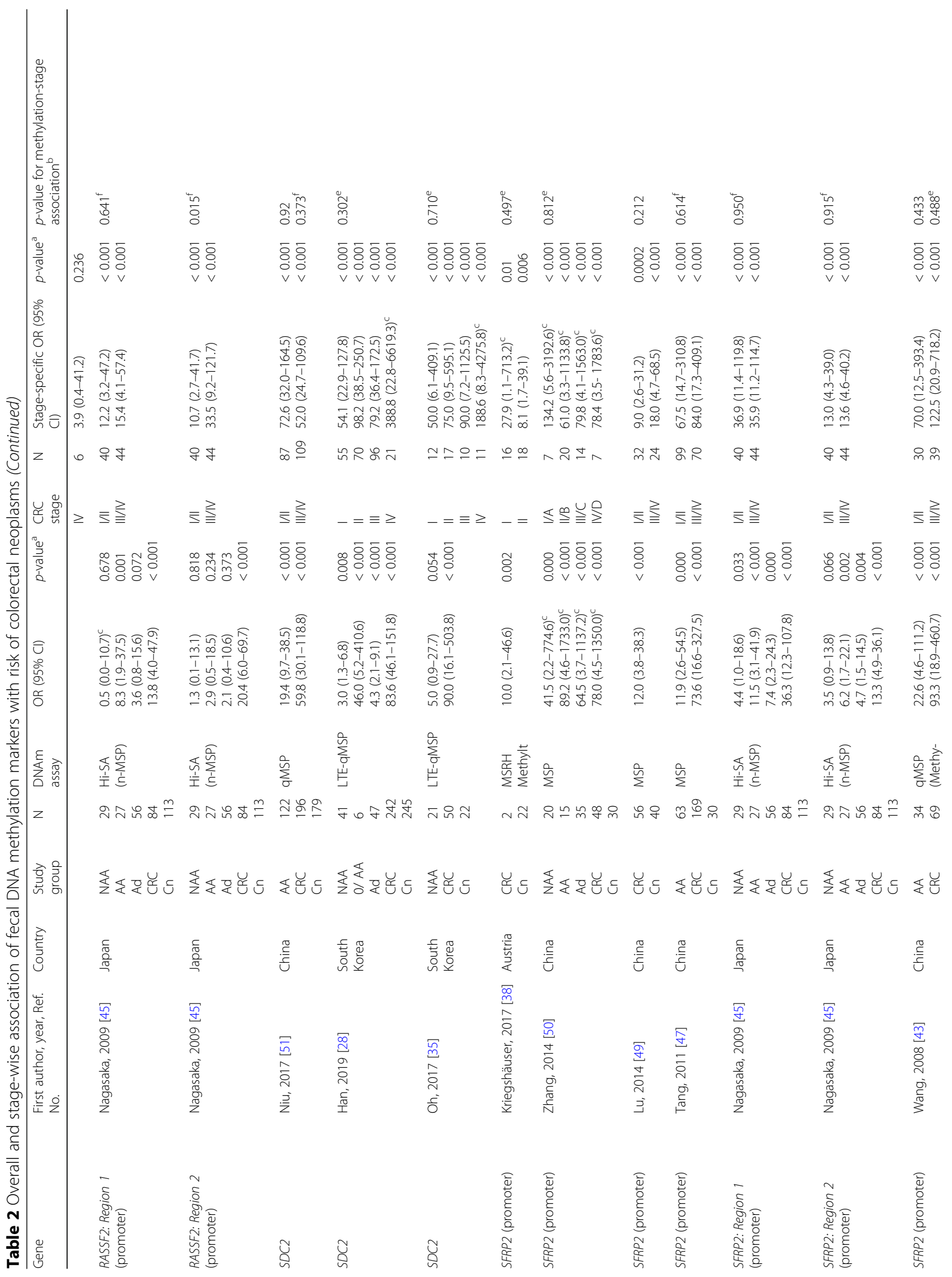




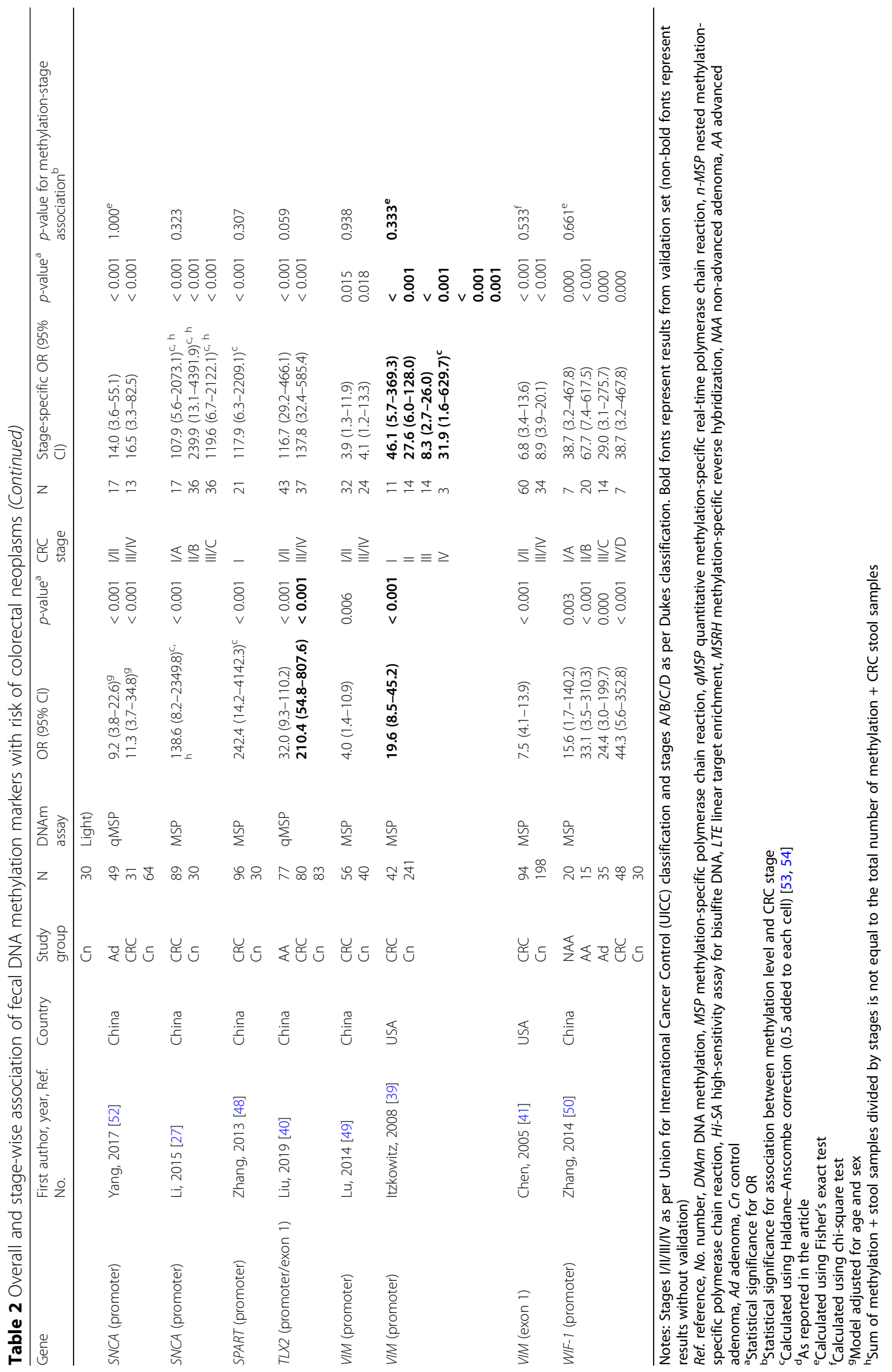


11 and 18 hypermethylated markers, significant associations were estimated with early (I/II) stages (ORs ranging from 3.9 to 116.7) and with late (III/IV) stages (ORs ranging from 4.1 to 190.0), respectively. In most of the studies, the methylation-CRC association was stronger when the outcome was restricted to advanced stages than to early stages. Only two stage-specific biomarkers (hypermethylation of GATA4 and VIM) were validated in independent samples [37, 39]. Hypermethylation of GATA4 showed a stronger association with advanced stages than early stages [37]. However, the association of hypermethylation of VIM to CRC risk was highest among stage I CRC cases, and no consistent pattern of association according to stage was observed for successive stages [39].

\section{Overall and stage-wise performance of fecal DNA methylation markers for detection of colorectal neoplasms}

An overview of the performance of fecal DNA methylation markers for detection of colorectal neoplasms is shown in Table 3. Sensitivities ranged from 0 to $72 \%, 7$ to $83 \%, 5$ to $76 \%$, and 20 to $94 \%$ for identifying NAA, AA, Ad, and CRC, respectively. Specificities ranged from 75 to $100 \%$. AUCs were reported only in six studies and were mostly reported without validation, except one study [40] which reported validated AUCs to discriminate CRC patients from control subjects. Liu et al. [40] reported that methylation levels in the promoter or exon regions of four genes, namely COL4A1, COL4A2, ITGA4, and TLX2 could differentiate CRC patients from control subjects in independent populations, with AUC values ranging from 0.95 to 0.98 . SDC2 methylation levels evaluated in three studies could discriminate AA patients (44), a combined group including three AA patients along with CRC patients [28] and CRC patients [35, 51] from control subjects, with AUC values of 0.79, 0.90, and 0.92-0.93, respectively. In Yang et al.'s study, SNCA methylation levels were reported to discriminate Ad and CRC patients from control subjects, with AUC values of 0.77 and 0.84 , respectively [52]. Hellebrekers et al. assessed GATA4's performance in discriminating CRC cases from controls and reported an AUC of 0.81 (sensitivity $71 \%$, specificity $84 \%$ ) [37]. They further validated this performance in independent samples, resulting in a sensitivity of $51 \%$ at a specificity of $93 \%$ for identifying CRC cases. The performance of another marker in the promoter region of VIM was validated in independent samples, resulting in a sensitivity of $81 \%$ at a specificity of $82 \%$ for identifying CRC cases [39]. For the remaining markers, validation remains yet to be performed.

In stage-specific analyses, numbers of CRC cases in different stages were often small. The efficacy of most of the markers was higher for detecting the late stages compared to the early stages. Stage-specific performances were validated in independent samples for two biomarkers (hypermethylation of GATA4 and VIM) only $[37,39]$. Methylated GATA4 showed a higher sensitivity to detect late stages compared to early stages (59 vs. $48 \%$ ) at a specificity of $93 \%$ [37]. For methylated VIM, at a specificity of $82 \%$, reported sensitivity for identifying stage I (91\%) was higher than that for identifying stages II $(86 \%)$ or III $(64 \%)$. While the highest sensitivity was observed for identifying stage IV CRC cases (100\%), the number of cases was very small (three cases) for stage IV [39].

\section{DNA methylation panels}

Combinations of methylation markers as six different panels for detection of colorectal neoplasms were evaluated in six studies, none of which was further validated (Table 4). It was observed that multiple markers combined into a panel showed stronger associations than one marker alone. In Liu et al.'s study [40], when methylation levels of COL4A2 and TLX2 were combined, the OR for CRC risk was 422, which was higher than that for methylation levels of COL4A2 (133.9) and TLX2 (210), separately. Similarly, in Lu et al.'s study [49], ORs for individual associations of methylated SFRP2, GATA4/5, NDRG4, and VIM with CRC ranged from 4.0 to 24.6, but when combined into a panel (defined as presence of at least 1 methylation among the gene promoters), the OR increased to 50.1. In addition, the stagespecific associations were stronger for the panel (with ORs 27.9 and 89.6 for stages I/II and III/IV, respectively) compared to the stage-specific associations of individual markers (ORs ranging from 3.9 to 16.8 and 4.1 to 51.9 for stages I/II and III/IV, respectively). In five out of six studies, stronger associations were observed for advanced stages compared to early stages. However, none of the panels showed a statistically significant difference in methylation levels between stages $(p>0.05)$.

Regarding the screening performances, sensitivities ranged from 55 to $70 \%, 46$ to $88 \%, 60$ to $72 \%$, and 70 to 96\% for NAA, AA, Ad, and CRC, respectively. Stagespecific sensitivities ranged from 64 to $94 \%$ and 75 to $100 \%$ for stages I/II and III/IV, respectively (Table 5). Specificities ranged from 55 to $98 \%$. In stage-specific analyses, most of the studies showed that efficacy in detecting advanced stages of CRC was better than in early stage of CRC.

\section{Methylation levels of individual markers or panels by CRC stage}

Nine studies reported on the association between methylation levels of individual markers or panels and CRC stage (Tables 2 and 4). For the remaining studies, we evaluated the association between methylation levels of 


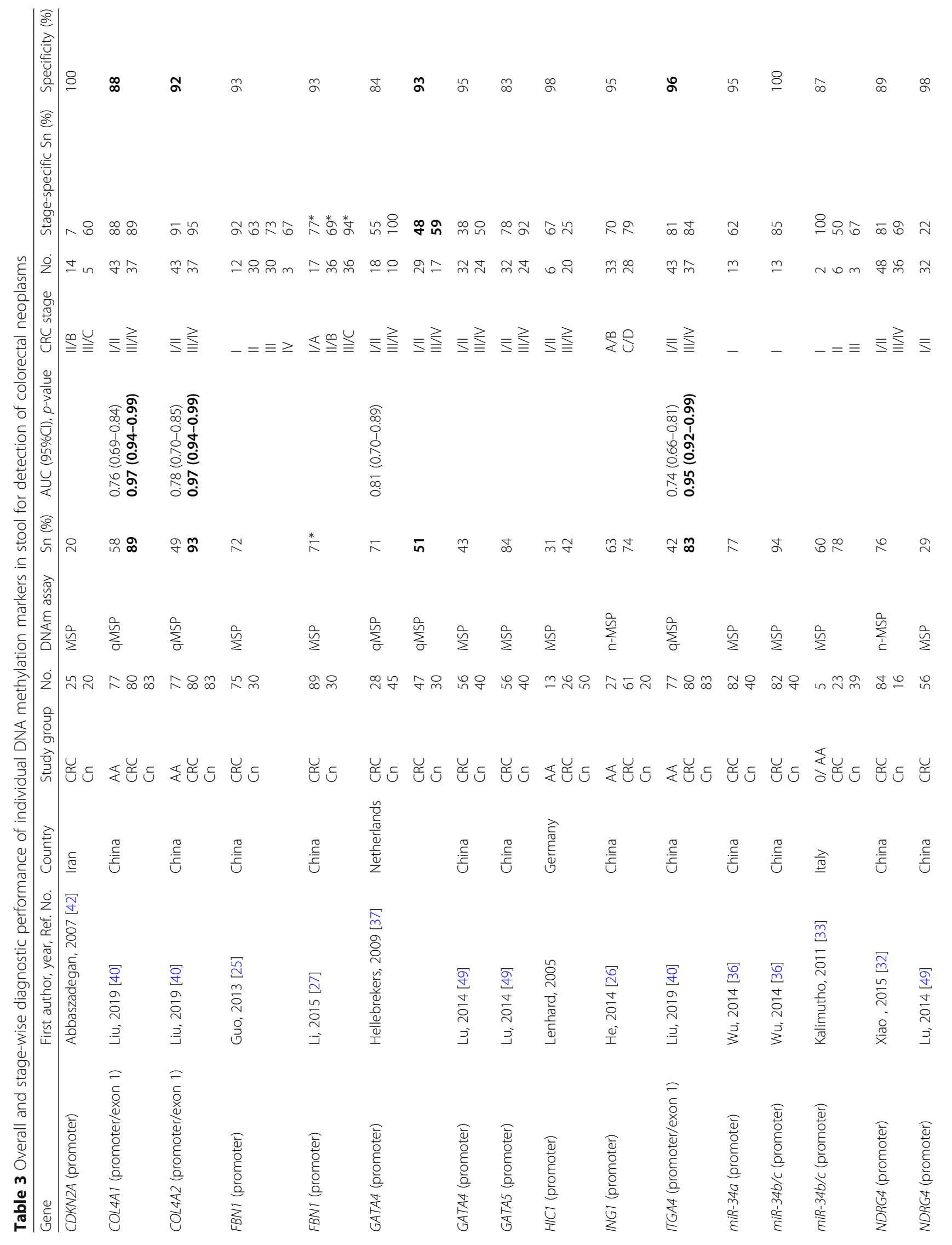




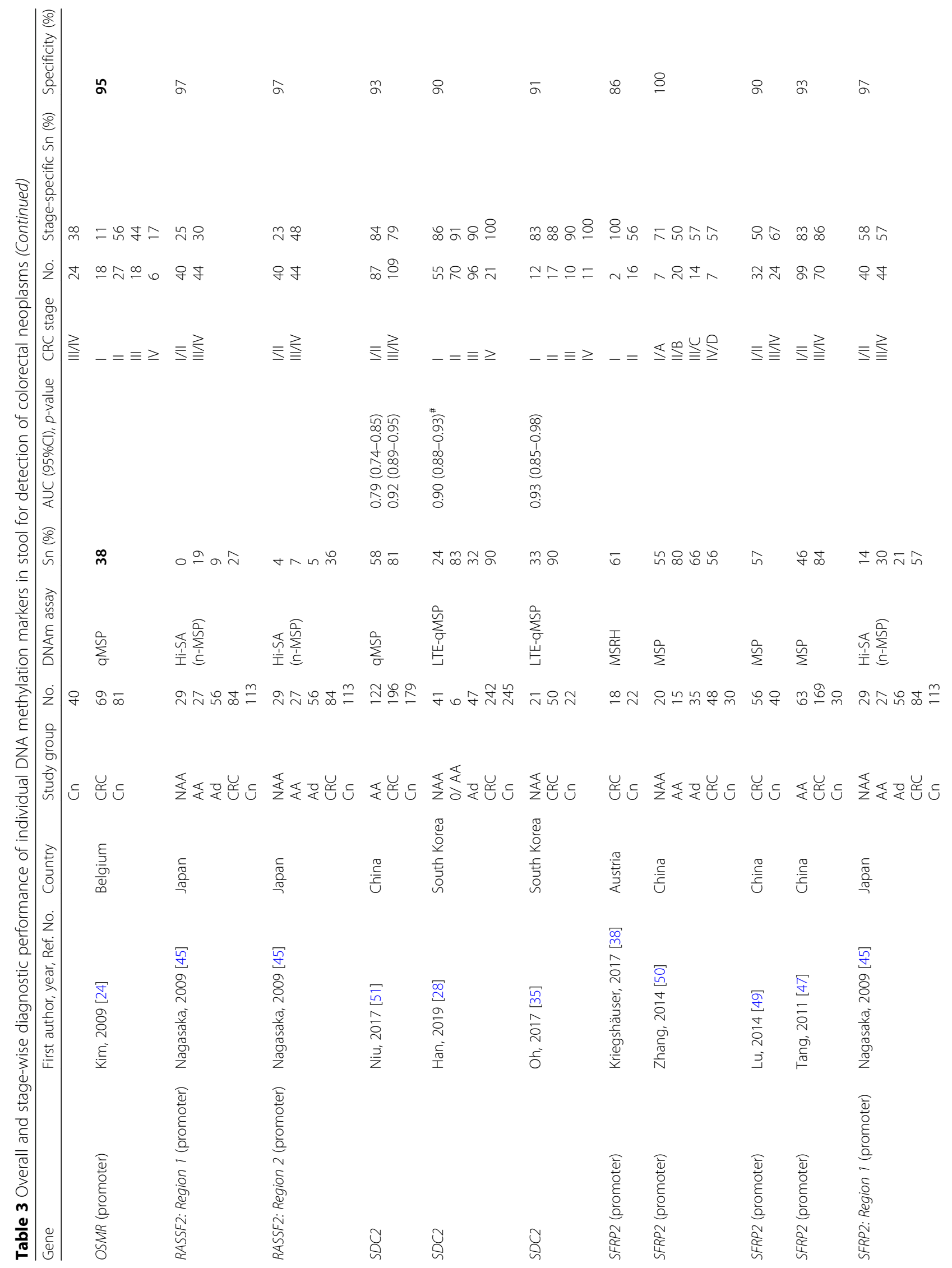




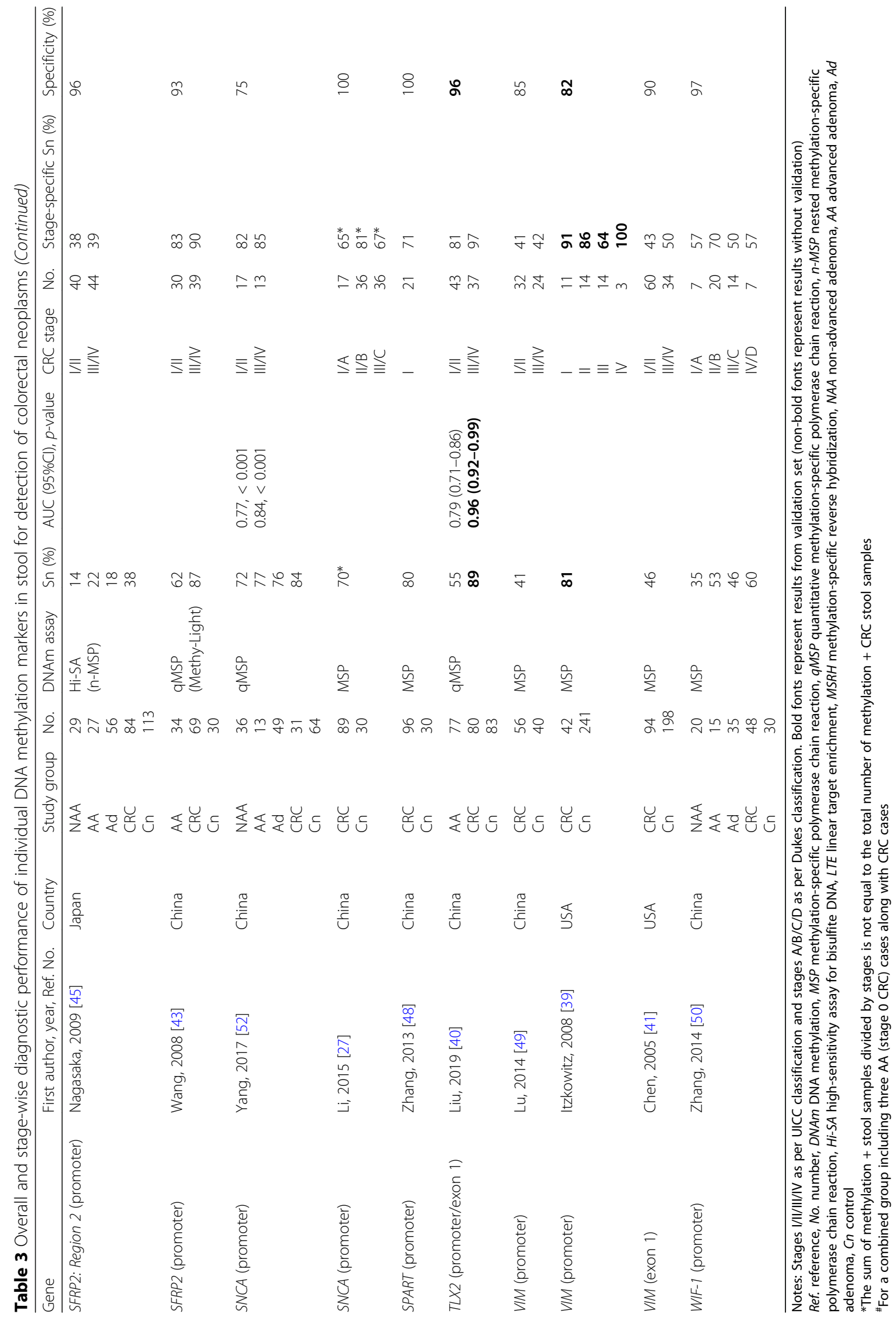


Table 4 Overall and stage-wise association of methylation panels in stool with risk of colorectal neoplasms

\begin{tabular}{|c|c|c|c|c|c|c|c|c|c|c|c|c|}
\hline Gene panel & $\begin{array}{l}\text { First author, } \\
\text { year, Ref. No. }\end{array}$ & Country & $\begin{array}{l}\text { Study } \\
\text { group }\end{array}$ & No. & $\begin{array}{l}\text { DNAm } \\
\text { assay }\end{array}$ & $\begin{array}{l}\text { OR }(95 \% \\
\mathrm{Cl})\end{array}$ & $p$-value ${ }^{a}$ & $\begin{array}{l}\text { CRC } \\
\text { stage }\end{array}$ & N & $\begin{array}{l}\text { Stage-specific } \\
\text { OR }(95 \% \text { Cl) }\end{array}$ & $p$-value ${ }^{\mathrm{a}}$ & $p$-value \\
\hline $\begin{array}{l}\text { MGMT, MLH1, and VIM } \\
\text { (promoters) }\end{array}$ & Baek, 2009 [44] & $\begin{array}{l}\text { South } \\
\text { Korea }\end{array}$ & $\begin{array}{l}\text { NAA } \\
\text { AA } \\
\text { Ad } \\
\text { CRC } \\
\text { Cn }\end{array}$ & $\begin{array}{l}30 \\
22 \\
52 \\
60 \\
37\end{array}$ & MSP & $\begin{array}{l}14.9(4.4- \\
50.8) \\
5.3(1.5- \\
18.8) \\
9.5(3.2- \\
28.2) \\
19.2(6.3- \\
58.2)\end{array}$ & $\begin{array}{l}<0.001 \\
0.01 \\
<0.001 \\
<0.001\end{array}$ & $\begin{array}{l}1 / I I \\
I I I / I V\end{array}$ & $\begin{array}{l}35 \\
25\end{array}$ & $\begin{array}{l}16.0(4.9-52.8) \\
25.6(6.6-99.7)\end{array}$ & $\begin{array}{l}<0.001 \\
<0.001\end{array}$ & 0.450 \\
\hline $\begin{array}{l}\text { ITGA4, SFRP2, and CDKN2A } \\
\text { (promoters) }\end{array}$ & $\begin{array}{l}\text { Chang, } 2010 \\
{[46]}\end{array}$ & Korea & $\begin{array}{l}\text { NAA } \\
\text { AA } \\
\text { Ad } \\
\text { CRC } \\
\text { Cn }\end{array}$ & $\begin{array}{l}17 \\
8 \\
25 \\
30 \\
31\end{array}$ & MSP & $\begin{array}{l}55.0(5.9- \\
509.9) \\
210.0 \\
(11.7- \\
3783.8) \\
77.1(8.8- \\
679.2) \\
70.0(8.2- \\
594.9)\end{array}$ & $\begin{array}{l}<0.001 \\
<0.001 \\
<0.001 \\
<0.001\end{array}$ & $\begin{array}{l}1 / \| \\
I I / / \mathrm{IV}\end{array}$ & $\begin{array}{l}14 \\
16\end{array}$ & $\begin{array}{l}54.0(5.6-524.0) \\
90.0(9.1-889.9)\end{array}$ & $\begin{array}{l}<0.001 \\
<0.001\end{array}$ & $0.694^{d}$ \\
\hline $\begin{array}{l}\text { SFRP2, GATA4/5, NDRG4, } \\
\text { and VIM (promoters) }\end{array}$ & Lu, 2014 [49] & China & $\begin{array}{l}\text { CRC } \\
\mathrm{Cn}\end{array}$ & $\begin{array}{l}56 \\
40\end{array}$ & MSP & $\begin{array}{l}50.1(10.6- \\
237.1)\end{array}$ & $<0.001$ & $\begin{array}{l}I / I \\
I I I / I V\end{array}$ & $\begin{array}{l}32 \\
24\end{array}$ & $\begin{array}{l}27.9(5.8-134.2) \\
89.6(5.1- \\
1583.0)^{c}\end{array}$ & $\begin{array}{l}<0.001 \\
<0.001\end{array}$ & $0.501^{d}$ \\
\hline $\begin{array}{l}\text { SFRP2 and WIF-1 } \\
\text { (promoters) }\end{array}$ & $\begin{array}{l}\text { Zhang, } 2014 \\
{[50]}\end{array}$ & China & $\begin{array}{l}\text { NAA } \\
\text { AA } \\
\text { Ad } \\
\text { CRC } \\
\text { Cn }\end{array}$ & $\begin{array}{l}20 \\
15 \\
35 \\
48 \\
30\end{array}$ & MSP & $\begin{array}{l}35.4(4.0- \\
313.4) \\
116.0 \\
(10.9- \\
1229.9) \\
55.6(6.7- \\
459.5) \\
125.7 \\
(15.1- \\
1048.2)\end{array}$ & $\begin{array}{l}<0.001 \\
<0.001 \\
<0.001 \\
<0.001\end{array}$ & $\begin{array}{l}1 / A \\
I I / B \\
I I / C \\
I V / D\end{array}$ & $\begin{array}{l}7 \\
20 \\
14 \\
7\end{array}$ & $\begin{array}{l}174.0(9.5- \\
3187.4) \\
116.0(11.9- \\
1128.2) \\
72.5(7.2-727.6) \\
295.0(10.9- \\
7994.2)^{c}\end{array}$ & $\begin{array}{l}<0.001 \\
<0.001 \\
<0.001 \\
<0.001\end{array}$ & $0.605^{d}$ \\
\hline $\begin{array}{l}\text { SFRP2, TFPI2, NDRG4, and } \\
\text { BMP3 (promoters) }\end{array}$ & Park, 2017 [34] & $\begin{array}{l}\text { South } \\
\text { Korea }\end{array}$ & $\begin{array}{l}\text { AA } \\
\text { CRC } \\
\text { Cn }\end{array}$ & $\begin{array}{l}36 \\
35 \\
40\end{array}$ & MSP & $\begin{array}{l}3.2(1.2- \\
8.3) \\
20.2(4.3- \\
95.7)\end{array}$ & $\begin{array}{l}0.017 \\
<0.001\end{array}$ & $\begin{array}{l}\mid / \| \\
I I / / \mathrm{IV}\end{array}$ & $\begin{array}{l}17 \\
18\end{array}$ & $\begin{array}{l}9.2(1.9-45.5) \\
45.0(2.5- \\
798.2)^{c}\end{array}$ & $\begin{array}{l}0.003 \\
0.000\end{array}$ & $0.229^{d}$ \\
\hline $\begin{array}{l}\text { COLAA2 and TLX2 } \\
\text { (promoter/exon 1) }\end{array}$ & Liu, 2019 [40] & China & $\begin{array}{l}\text { AA } \\
\text { CRC } \\
\text { Cn }\end{array}$ & $\begin{array}{l}77 \\
80 \\
83\end{array}$ & qMSP & $\begin{array}{l}43.8(10.0- \\
190.9) \\
422.4 \\
(85.0- \\
2098.2)\end{array}$ & $\begin{array}{l}<0.001 \\
<0.001\end{array}$ & $\begin{array}{l}I / I \\
I I I / I V\end{array}$ & $\begin{array}{l}43 \\
37\end{array}$ & $\begin{array}{l}249.8(48.1- \\
1296.4) \\
1458.0(128.1- \\
16,600.2)\end{array}$ & $\begin{array}{l}<0.001 \\
<0.001\end{array}$ & 0.168 \\
\hline
\end{tabular}

Note: Stages I/II/III/IV as per UICC classification and stages A/B/C/D as per Dukes classification

Ref. reference, No. number, DNAm DNA methylation, MSP methylation-specific polymerase chain reaction, qMSP quantitative methylation-specific real-time polymerase chain reaction, $n-M S P$ nested methylation-specific polymerase chain reaction, Hi-SA high-sensitivity assay for bisulfite DNA, LTE linear target enrichment, MSRH methylation-specific reverse hybridization, NAA non-advanced adenoma, $A A$ advanced adenoma, Ad adenoma, Cn control

${ }^{\text {a }}$ Statistical significance for OR

${ }^{\mathrm{b}}$ Statistical significance for association between methylation level and CRC stage ${ }^{c}$ Calculated using Haldane-Anscombe correction (0.5 added to each cell) $[53,54]$

${ }^{\mathrm{d} C a l c u l a t e d}$ using Fisher's exact test

individual markers or panels and CRC stage using chi-square or Fisher's exact test. A significant stepwise increase in methylation levels of CDKN2A $(p=$ 0.04) [42], OSMR ( $p=0.01)$ [24], and RASSF2: Region $2(p=0.02)[45]$ promoters with stage was observed, with higher levels in advanced stage patients compared with early stage patients. For the remaining individual markers or panels, the difference in methylation levels between stages was not statistically significant $(p>0.05)$.

\section{Quality assessment of studies}

The results for the quality assessment of studies using the QUADAS tool are presented in Figures S1 and S2 (see Additional file 1). The greatest potential risk of bias came from patient selection as all but two studies selected participants in clinical settings rather than screening settings. Most studies (23/27) were rated as having unclear risk of bias for the index test due to lack of information on whether a pre-specified threshold was used and interpretation of results without conducting 
Table 5 Overall and stage-wise performance of methylation panels in stool for detection of colorectal neoplasms

\begin{tabular}{|c|c|c|c|c|c|c|c|c|c|c|}
\hline Gene panel & $\begin{array}{l}\text { First author, year, } \\
\text { Ref. No. }\end{array}$ & Country & $\begin{array}{l}\text { Study } \\
\text { group }\end{array}$ & No. & $\begin{array}{l}\text { DNA methylation } \\
\text { assay }\end{array}$ & $\begin{array}{l}\mathrm{Sn} \\
(\%)\end{array}$ & $\begin{array}{l}\text { CRC } \\
\text { stage }\end{array}$ & No. & $\begin{array}{l}\text { Stage-specific } \\
\text { Sn (\%) }\end{array}$ & $\begin{array}{l}\text { Sp } \\
(\%)\end{array}$ \\
\hline $\begin{array}{l}\text { MGMT, MLH1, and VIM } \\
\text { (promoters) }\end{array}$ & Baek, 2009 [44] & $\begin{array}{l}\text { South } \\
\text { Korea }\end{array}$ & $\begin{array}{l}\text { NAA } \\
\text { AA } \\
\text { Ad } \\
\text { CRC } \\
\text { Cn }\end{array}$ & $\begin{array}{l}30 \\
22 \\
52 \\
60 \\
37\end{array}$ & MSP & $\begin{array}{l}70 \\
46 \\
60 \\
75\end{array}$ & $\begin{array}{l}I / \| \\
\| I / I V\end{array}$ & $\begin{array}{l}35 \\
25\end{array}$ & $\begin{array}{l}71 \\
80\end{array}$ & 87 \\
\hline $\begin{array}{l}\text { ITGA4, SFRP2, and CDKN2A } \\
\text { (promoters) }\end{array}$ & Chang, 2010 [46] & Korea & $\begin{array}{l}\text { NAA } \\
\text { AA } \\
\text { Ad } \\
\text { CRC } \\
\text { Cn }\end{array}$ & $\begin{array}{l}17 \\
8 \\
25 \\
30 \\
31\end{array}$ & MSP & $\begin{array}{l}65 \\
88 \\
72 \\
70\end{array}$ & $\begin{array}{l}1 / \| \\
\| 1 / / \mathrm{IV}\end{array}$ & $\begin{array}{l}14 \\
16\end{array}$ & $\begin{array}{l}64 \\
75\end{array}$ & 97 \\
\hline $\begin{array}{l}\text { SFRP2, GATA4/5, NDRG4 and VIM } \\
\text { (promoters) }\end{array}$ & Lu, 2014 [49] & China & $\begin{array}{l}\text { CRC } \\
\mathrm{Cn}\end{array}$ & $\begin{array}{l}56 \\
40\end{array}$ & MSP & 96 & $\begin{array}{l}\mid / \| \\
\| I / I V\end{array}$ & $\begin{array}{l}32 \\
24\end{array}$ & $\begin{array}{l}94 \\
100\end{array}$ & 65 \\
\hline SFRP2 and WIF-1 (promoters) & Zhang, 2014 [50] & China & $\begin{array}{l}\text { NAA } \\
\text { AA } \\
\text { Ad } \\
\text { CRC } \\
\text { Cn }\end{array}$ & $\begin{array}{l}20 \\
15 \\
35 \\
48 \\
30\end{array}$ & MSP & $\begin{array}{l}55 \\
80 \\
66 \\
81\end{array}$ & $\begin{array}{l}\text { I/A } \\
\| / B \\
\text { III/C } \\
\text { IV/D }\end{array}$ & $\begin{array}{l}7 \\
20 \\
14 \\
7\end{array}$ & $\begin{array}{l}86 \\
80 \\
71 \\
100\end{array}$ & 97 \\
\hline $\begin{array}{l}\text { SFRP2, TFPI2, NDRG4, and BMP3 } \\
\text { (promoters) }\end{array}$ & Park, 2017 [34] & $\begin{array}{l}\text { South } \\
\text { Korea }\end{array}$ & $\begin{array}{l}\text { AA } \\
\text { CRC } \\
\text { Cn }\end{array}$ & $\begin{array}{l}36 \\
35 \\
40\end{array}$ & MSP & $\begin{array}{l}72 \\
94\end{array}$ & $\begin{array}{l}\mid / \| \\
\| I / / V\end{array}$ & $\begin{array}{l}17 \\
18\end{array}$ & $\begin{array}{l}88 \\
100\end{array}$ & 55 \\
\hline $\begin{array}{l}\text { COLAA2 and TLX2 (promoter/exon } \\
\text { 1) }\end{array}$ & Liu, 2019 [40] & China & $\begin{array}{l}\text { AA } \\
\text { CRC } \\
\text { Cn }\end{array}$ & $\begin{array}{l}77 \\
80 \\
83\end{array}$ & qMSP & $\begin{array}{l}52 \\
91\end{array}$ & $\begin{array}{l}\mid / \| \\
\| I / / V\end{array}$ & $\begin{array}{l}43 \\
37\end{array}$ & $\begin{array}{l}86 \\
97\end{array}$ & 98 \\
\hline
\end{tabular}

Note: Stages I/II/III/IV as per UICC classification and stages A/B/C/D as per Dukes classification

Ref. reference, No. number, Sn sensitivity, $S p$ specificity, MSP methylation-specific polymerase chain reaction, qMSP quantitative methylation-specific real-time polymerase chain reaction, NAA non-advanced adenoma, AA advanced adenoma, $A d$ adenoma, Cn Control

validation studies. For most of the studies, there was no concern of bias for the reference standard. The risk of bias for flow and timing was low for 20 studies and unclear for 7 studies. Applicability concerns were high for patient selection as most of the studies collected blood samples from symptomatic cases at the time of diagnosis rather than evaluating samples of participants recruited in true screening settings.

\section{Discussion}

Identification of stage-specific DNA methylation biomarkers in stool could boost current screening strategies towards early-stage detection and enable different approaches to precision medicine for CRC. In this systematic literature review, we identified twenty-seven studies evaluating twenty-five fecal methylation markers for detection of different stages of CRC and its precursors. The most frequently used platform for assessing methylation was MSP with various modifications. Multiple methylation markers showed significant associations with NAA, AA, Ad, TNM stages I-IV, and overall CRC in either univariate or multivariate regression analysis. A majority of the studies showed that the efficacy of either single methylation biomarkers or biomarker panels was higher for detecting advanced CRC stages compared to early CRC stages. However, most of the studies had relatively small sample sizes which might have limited the assessment of efficacy to detect colorectal neoplasms at different stages. Furthermore, most of the findings according to cancer stage lacked any form of validation.

We identified twenty-four studies reporting stagespecific results for individual markers. In a study by Guo et al. [25], a promising marker for stage I CRC detection was identified in the promoter region of FBN1. The marker showed a $92 \%$ sensitivity at $93 \%$ specificity (OR $=154.0,95 \% \mathrm{CI}=12.7-1875.6, p<0.001)$ for detecting stage I CRC. Another marker in the gene SDC2 reported by $\mathrm{Han}$ et al. [28] showed a promising performance for stage II CRC detection with $91 \%$ sensitivity at $90 \%$ specificity $(\mathrm{OR}=98.2,95 \% \mathrm{CI}=38.5-250.7, p<0.001)$. However, these findings should be interpreted with caution, considering that they were from studies with relatively small number of stage-specific cases and are yet to be validated in larger independent samples. Validation in an independent cohort was performed in a study by Itzkowitz et al. [39], resulting in the identification of a promising marker in the promoter region of VIM. While the stage-specific numbers of cases were small (3-14), the marker showed high sensitivities of $91 \%, 86 \%, 64 \%$, and $100 \%$ for stages I-IV respectively at $82 \%$ specificity in the validation set.

The majority of findings in this review came from case control studies in different populations that varied in quality. A key feature of diagnostic biomarker identification studies is that the participants should reflect the screening population and the recruitment conditions for 
cases, and controls should be fully comparable. However, the studies mostly recruited participants in clinical settings rather than screening settings, introducing the potential of selection bias that might have influenced the results. Of the twenty-seven reviewed studies, twenty studies were conducted in Asian populations, limiting the overall generalizability of the results. Furthermore, the relatively small size of most of these studies resulted in inadequate power to estimate stage-specific results in stratified analyses. When selecting cases, of the twentyseven reviewed studies, only fourteen studies included AAs which have a high risk of transformation to cancer and would be most relevant to stratify risk for developing CRC. In order to identify promising stage-specific biomarkers for CRC screening, there is a need for largescale prospective screening cohorts from populations that are diverse with respect to geography, age, and sex.

Regarding sample collection, storage, and pretreatment steps for methylation assays, we found that a substantial heterogeneity existed among the included studies. This may have contributed, in part, to inconsistent DNA methylation measurements. Although the advantages of adding stabilization buffer to stool samples during collection (to guarantee the most consistent yield in human DNA) have been effectively demonstrated [55], not all studies reported using a preservative buffer while sample collection. There was great variation (30 $\mathrm{min}-12 \mathrm{~h}$ after defecation) in the time intervals between completed collection and placement of the samples in the laboratory freezer, where they were frozen at varying temperatures $\left(-80\right.$ to $4{ }^{\circ} \mathrm{C}$ ) until DNA extraction. Only some studies reported centrifuging the samples before freezing. The studies also used different amounts of starting material (180-300 mg) and kits for extracting DNA from samples including QIAamp DNA Stool Mini Kit, TIANamp Genomic DNA kit, Stool DNA Extraction kit (Bioneer Corporation), and precipitation DNA pellet by centrifugation. DNA concentration was measured in some studies using Qubit dsDNA BR assay kit or ultraviolet spectrophotography. Few studies verified the quality of DNA by agarose gel electrophoresis and polymerase chain reaction (PCR) amplification of the human $\beta$-actin. Furthermore, the studies used varying amounts $(500 \mathrm{ng}-2 \mu \mathrm{g}$ ) of genomic DNA for bisulfite conversion using different kits including EZ DNA Methylation-Gold kit (ZYMO Research, USA) and EpiTect Bisulfite Kit (Qiagen). Bisulfite-converted DNA was either used immediately for methylation analysis or stored at $-20^{\circ} \mathrm{C}$ until further use. While template amount of DNA in the PCR is the largest contributor of technical variability in bisulfite PCR-based DNA methylation analyses, storage of bisulfite converted DNA, DNA input in the bisulfite conversion reaction, and type of bisulfite kit also contribute to various degrees of variability [56]. Thus, standardization of these methodological approaches is critical to improve the reliability of findings and replication across studies.

The selection of the genomic regions to be studied is one of the critical challenges to establishing DNA methylation biomarkers that are clinically useful. An unbiased genome-wide screening approach would help discover novel sites and genes of interest. So far, all studies have been based on candidate gene approaches and very few studies investigated DNA methylation in the same gene. Assessment of DNA methylation in all studies was using MSP, which interrogates only a few CpGs (in the gene promoters in most of the studies), serving as a surrogate for the methylation status of the whole region. As methylation patterns often vary largely across genomic regions and are poorly defined [57, 58], analysis of sequence stretches with multiple CpGs (small groups of CpGs (CpG units), regional methylation changes, or site clusters) is less informative compared to analysis at single nucleotide resolution (quantification of methylation for individual CpGs). Furthermore, to make it easier to transfer technologies to different labs and to create clinical standards, the use of methods that deliver quantitative methylation data is desirable. Among the reviewed studies, fifteen studies used conventional MSP, three studies used nested MSP, and nine studies used qMSP. Although MSP is a highly sensitive method, especially when nested PCR approaches are used, it is not quantitative and bears a significant risk of false-positive results and variability of results due to assay conditions (e.g., primer design, annealing temperature, cycle number) [59-61]. While a few studies used qMSP which is highly specific and more sensitive than conventional PCR, the method still provides a low coverage of CpGs [61, 62]. Given the availability of new high-throughput technologies that are able to investigate DNA methylation in a genome-wide manner, future studies should make use of these to allow for unbiased methylation analysis of a large number of CpGs.

A critical factor affecting the clinical utility of a molecular biomarker is specificity. Low specificity results in high numbers of false-positive results, exposing the patient to unnecessary invasive evaluation, with adverse consequences and increased cost of care. It is well recognized that methylation biomarkers, particularly those identified using non-quantitative MSP-based methodologies and poorly controlled enzyme-based approaches are prone to generating false-positive results [59-61]. The most well-studied blood-based screening marker SEPT9 methylation has also been associated with false-positive results $[63,64]$. Since most of the reviewed studies used conventional MSP, these results must be very carefully interpreted. Replication of the significant findings in future studies is of paramount importance in order to limit 
the number of false-positives. Specificity of methylation markers could be improved by studying the biological role of a biomarker and considering tissue-specific methylation patterns in the gene of interest to distinguish the truly cancer-related aberrant methylation event from baseline methylation.

Compared to molecular markers such as methylation of SEPT9 $[19,65,66]$ in tumor-derived cell-free DNA, microRNA signatures in various biofluids (plasma, serum, or stool) [67-69], genetic [70, 71], or proteomic markers [72-74] performance of methylation markers in stool DNA for detecting various stages of CRC seems poorer. In the reviewed studies, methylation of several genes was associated with increased risk of NAA/AA/Ad, early and late stages of CRC, supporting a role of DNA methylation at all stages of CRC, and suggesting potential use of these biomarkers for risk stratification in CRC screening. Nevertheless, evidence is lacking on whether the methylation-CRC association could vary by cancer stage. Stronger methylation-CRC association in the few cases of advanced stages than early stages should be interpreted with caution considering that they are from small-scale studies with crosssectional data. Large-scale prospective studies conducted in true screening settings are needed before we can draw an inference that, for example, these markers are measurable in early and late stages of colorectal carcinogenesis. Furthermore, more studies should provide stage-specific analyses to explore the relationship of gene-specific methylation with various stages of CRC.

This review offers a comprehensive overview of all diagnostic stool DNA methylation biomarkers investigated in separate stages of colorectal carcinogenesis from NAA to CRC stages I-IV. We comprehensively extracted all relevant information from twenty-seven identified studies and completed a quality assessment using a recognized evaluation tool [31]. Our review has several limitations. Despite comprehensive search in two wellestablished databases and cross-referencing, it is possible that some relevant studies were missed, especially those published in languages other than English. Several studies had to be excluded in full text review because they did not report any stage-specific measure of diagnostic performance or measure of association and did not provide enough data to calculate them. Such selective reporting could have introduced an outcome reporting bias [75]. We could not combine the results of independent studies as a meta-analysis due to a substantial heterogeneity existing across the reviewed studies. Finally, associations between methylation markers in stool and stage of colorectal carcinogenesis cannot be established from the reviewed studies.

\section{Conclusion}

Our review suggests the possibility of using stool-based methylation markers for risk stratification or stagespecific detection of CRC and its precursors, as a number of studies support an association between methylation changes in stool and different stages of CRC. A number of promising methylation markers have been reported, but optimized stage-specific markers are yet to be developed and promising candidate markers need to be validated in prospective study cohorts and tested in large screening populations by well-designed studies. While the investigation of methylation changes in stool DNA holds great promises, future studies should apply more standardized methods and use unbiased genomewide methylation analyses to define a consistent panel of stool DNA methylation biomarkers for CRC early detection and staging. This work will further the research into clinically useful biomarkers and could potentially lead not only to concise and timely diagnosis of CRC, but possibly to the discovery of predictive markers associated with CRC stages.

\section{Supplementary information}

Supplementary information accompanies this paper at https://doi.org/10. 1186/s13148-020-00904-7.

Additional file 1: Table S1. PRISMA 2009 Checklist. Table S2. Study characteristics of reviewed studies. Figure S1. Risk of bias and applicability concerns graph: review authors' judgements about each domain presented as percentages across included studies. Figure S2. Risk of bias and applicability concerns summary: review authors' judgements about each domain for each included study.

\section{Abbreviations}

AA: Advanced colorectal adenoma; Ad: Colorectal adenoma; AUC: Area under the receiver operating characteristics curve; Cl: Confidence intervals; CpG: Cytosine-phosphate-guanine; CRC: Colorectal cancer; MSP: Methylationspecific polymerase chain reaction; MSRH: Methylation-specific reverse hybridization assay; NAA: Non-advanced colorectal adenoma; OR: Odds ratio; qMSP: Quantitative methylation-specific real-time polymerase chain reaction; QUADAS: Quality Assessment of Diagnostic Accuracy Studies

\section{Acknowledgements}

Not applicable.

\section{Authors' contributions}

$\mathrm{HB}$ designed and supervised the study. JRR undertook the systematic literature search and drafted the manuscript. JRR and ZG extracted data from eligible studies. JRR, ZG, PSK, and HB critically reviewed the manuscript and approved the final draft

\section{Funding}

No funding was involved in the preparation of this manuscript.

\section{Availability of data and materials}

All data collected, generated, or analyzed during this study are included in this published article, or available as its additional file.

Ethics approval and consent to participate

Ethics approval was given within each individual study included in this review. 


\section{Consent for publication}

Not applicable.

\section{Competing interests}

The authors declare that they have no competing interests.

\section{Author details}

${ }^{1}$ Division of Preventive Oncology, German Cancer Research Center (DKFZ) and National Center for Tumor Diseases (NCT), Heidelberg, Germany. ${ }^{2}$ Medical Faculty Heidelberg, University of Heidelberg, Heidelberg, Germany. ${ }^{3}$ Division of Clinical Epidemiology and Aging Research, German Cancer Research Center (DKFZ), Heidelberg, Germany. ${ }^{4}$ German Cancer Consortium (DKTK), German Cancer Research Center (DKFZ), Heidelberg, Germany.

Received: 13 April 2020 Accepted: 9 July 2020

Published online: 10 August 2020

\section{References}

1. Bray F, Ferlay J, Soerjomataram I, Siegel RL, Torre LA, Jemal A. Global cancer statistics 2018: GLOBOCAN estimates of incidence and mortality worldwide for 36 cancers in 185 countries. CA Cancer J Clin. 2018.

2. Nishihara R, Wu K, Lochhead P, Morikawa T, Liao X, Qian ZR, et al. Longterm colorectal-cancer incidence and mortality after lower endoscopy. N Engl J Med. 2013;369(12):1095-105.

3. Shaukat A, Mongin SJ, Geisser MS, Lederle FA, Bond JH, Mandel JS, et al. Long-term mortality after screening for colorectal cancer. N Engl J Med. 2013;369(12):1106-14.

4. Brenner $\mathrm{H}$, Stock C, Hoffmeister M. Effect of screening sigmoidoscopy and screening colonoscopy on colorectal cancer incidence and mortality: systematic review and meta-analysis of randomised controlled trials and observational studies. BMJ (Clin Res ed). 2014;348:g2467.

5. Hassan C, Giorgi Rossi P, Camilloni L, Rex DK, Jimenez-Cendales B, Ferroni E, et al. Meta-analysis: adherence to colorectal cancer screening and the detection rate for advanced neoplasia, according to the type of screening test. Aliment Pharmacol Ther. 2012;36(10):929-40.

6. Young PE, Womeldorph CM. Colonoscopy for colorectal cancer screening. J Cancer. 2013;4(3):217-26.

7. Kim SY, Kim HS, Park HJ. Adverse events related to colonoscopy: global trends and future challenges. World J Gastroenterol. 2019;25(2):190-204.

8. Niedermaier T, Balavarca Y, Brenner H. Stage-specific sensitivity of fecal immunochemical tests for detecting colorectal cancer: systematic review and meta-analysis. Am J Gastroenterol. 2020;115(1):56-69.

9. Niedermaier T, Tikk K, Gies A, Bieck S, Brenner H. Sensitivity of fecal immunochemical test for colorectal cancer detection differs according to stage and location. Clin Gastroenterol Hepatol. 2020.

10. Fearon ER. Molecular genetics of colorectal cancer. Annu Rev Pathol. 2011;6: 479-507.

11. Pancione M, Remo A, Colantuoni V. Genetic and epigenetic events generate multiple pathways in colorectal cancer progression. Pathol Res Int. 2012; 2012:509348.

12. Hong SN. Genetic and epigenetic alterations of colorectal cancer. Intest Res. 2018;16(3):327-37.

13. Andersen GB, Tost J. A summary of the biological processes, diseaseassociated changes, and clinical applications of DNA methylation. Methods Mol Biol. 2018;1708:3-30.

14. Song L, Li Y. SEPT9: a specific circulating biomarker for colorectal cancer. Adv Clin Chem. 2015;72:171-204.

15. Durso DF, Bacalini MG, do Valle IF, Pirazzini C, Bonafe M, Castellani G, et al. Aberrant methylation patterns in colorectal cancer: a meta-analysis. Oncotarget. 2017;8(8):12820-30.

16. Heiss JA, Brenner H. Epigenome-wide discovery and evaluation of leukocyte DNA methylation markers for the detection of colorectal cancer in a screening setting. Clin Epigenetics. 2017:9:24.

17. Raut JR, Guan Z, Schrotz-King P, Brenner H. Whole-blood DNA methylation markers for risk stratification in colorectal cancer screening: a systematic review. Cancers (Basel). 2019;11(7).

18. Imperiale TF, Ransohoff DF, Itzkowitz SH, Levin TR, Lavin P, Lidgard GP, et al. Multitarget stool DNA testing for colorectal-cancer screening. N Engl J Med. 2014;370(14):1287-97.
19. Potter NT, Hurban P, White MN, Whitlock KD, Lofton-Day CE, Tetzner R, et al. Validation of a real-time PCR-based qualitative assay for the detection of methylated SEPT9 DNA in human plasma. Clin Chem. 2014;60(9):1183-91.

20. Lamb YN, Dhillon S. Epi proColon((R)) 2.0 CE: a blood-based screening test for colorectal cancer. Mol Diag Ther. 2017;21(2):225-32.

21. Berger BM, Ahlquist DA. Stool DNA screening for colorectal neoplasia: biological and technical basis for high detection rates. Pathology. 2012; 44(2):80-8.

22. Chen JJ, Wang $A Q$, Chen QQ. DNA methylation assay for colorectal carcinoma. Cancer Biol Med. 2017;14(1):42-9.

23. Lenhard K, Bommer GT, Asutay S, Schauer R, Brabletz T, Goke B, et al. Analysis of promoter methylation in stool: a novel method for the detection of colorectal cancer. Clin Gastroenterol Hepatol. 2005;3(2):142-9.

24. Kim MS, Louwagie J, Carvalho B, Terhaar Sive Droste JS, Park HL, Chae YK, et al. Promoter DNA methylation of oncostatin $m$ receptor-beta as a novel diagnostic and therapeutic marker in colon cancer. PLoS One. 2009;4(8):e6555.

25. Guo Q, Song Y, Zhang H, Wu X, Xia P, Dang C. Detection of hypermethylated fibrillin-1 in the stool samples of colorectal cancer patients. Med Oncol (Northwood, London, England). 2013;30(4):695.

26. He CG, Huang QY, Chen LS, Ling ZA, Wu HG, Deng HQ. p33(ING1b) methylation in fecal DNA as a molecular screening tool for colorectal cancer and precancerous lesions. Oncol Lett. 2014;7(5):1639-44.

27. Li WH, Zhang H, Guo Q, Wu XD, Xu ZS, Dang CX, et al. Detection of SNCA and FBN1 methylation in the stool as a biomarker for colorectal cancer. Dis Markers. 2015;2015:657570

28. Han YD, Oh TJ, Chung TH, Jang HW, Kim YN, An S, et al. Early detection of colorectal cancer based on presence of methylated syndecan-2 (SDC2) in stool DNA. Clin Epigenetics. 2019;11 (1):51.

29. McMahon KW, Karunasena E, Ahuja N. The roles of DNA methylation in the stages of cancer. Cancer J. 2017;23(5):257-61.

30. Moher D, Liberati A, Tetzlaff J, Altman DG. Preferred reporting items for systematic reviews and meta-analyses: the PRISMA statement. Int I Surg (London, England). 2010;8(5):336-41.

31. Whiting PF, Rutjes AW, Westwood ME, Mallett S, Deeks JJ, Reitsma JB, et al. QUADAS-2: a revised tool for the quality assessment of diagnostic accuracy studies. Ann Intern Med. 2011;155(8):529-36.

32. Xiao W, Zhao H, Dong W, Li Q, Zhu J, Li G, et al. Quantitative detection of methylated NDRG4 gene as a candidate biomarker for diagnosis of colorectal cancer. Oncol Lett. 2015;9(3):1383-7.

33. Kalimutho M, Di Cecilia S, Del Vecchio BG, Roviello F, Sileri P, Cretella M, et al. Epigenetically silenced miR-34b/c as a novel faecal-based screening marker for colorectal cancer. Br J Cancer. 2011;104(11):1770-8.

34. Park SK, Baek HL, Yu J, Kim JY, Yang HJ, Jung YS, et al. Is methylation analysis of SFRP2, TFPI2, NDRG4, and BMP3 promoters suitable for colorectal cancer screening in the Korean population? Intestinal Res. 2017;15(4):495-501.

35. Oh TJ, Oh HI, Seo YY, Jeong D, Kim C, Kang HW, et al. Feasibility of quantifying SDC2 methylation in stool DNA for early detection of colorectal cancer. Clin Epigenetics. 2017;9:126.

36. Wu XD, Song YC, Cao PL, Zhang H, Guo Q, Yan R, et al. Detection of miR$34 \mathrm{a}$ and $\mathrm{miR}-34 \mathrm{~b} / \mathrm{c}$ in stool sample as potential screening biomarkers for noninvasive diagnosis of colorectal cancer. Med Oncol (Northwood, London, England). 2014;31(4):894.

37. Hellebrekers DM, Lentjes MH, van den Bosch SM, Melotte V, Wouters KA, Daenen KL, et al. GATA4 and GATA5 are potential tumor suppressors and biomarkers in colorectal cancer. Clin Cancer Res. 2009;15(12):3990-7.

38. Kriegshauser G, Enko D, Zitt M, Oberwalder M, Oberkanins C, Ofner D, et al. Comparison of a prototype reverse hybridization assay and MethyLight for detection of SFRP2 promotor methylation in fecal DNA. Int J Biol Markers. 2017;32(4):e467-e70.

39. Itzkowitz S, Brand R, Jandorf L, Durkee K, Millholland J, Rabeneck L, et al. A simplified, noninvasive stool DNA test for colorectal cancer detection. Am J Gastroenterol. 2008;103(11):2862-70.

40. Liu X, Wen J, Li C, Wang H, Wang J, Zou H. High-yield methylation markers for stool-based detection of colorectal cancer. Dig Dis Sci. 2019.

41. Chen WD, Han ZJ, Skoletsky J, Olson J, Sah J, Myeroff L, et al. Detection in fecal DNA of colon cancer-specific methylation of the nonexpressed vimentin gene. J Natl Cancer Inst. 2005;97(15):1124-32.

42. Abbaszadegan MR, Tavasoli A, Velayati A, Sima HR, Vosooghinia H, Farzadnia $\mathrm{M}$, et al. Stool-based DNA testing, a new noninvasive method for colorectal cancer screening, the first report from Iran. World J Gastroenterol. 2007; 13(10):1528-33. 
43. Wang DR, Tang D. Hypermethylated SFRP2 gene in fecal DNA is a high potential biomarker for colorectal cancer noninvasive screening. World $\rfloor$ Gastroenterol. 2008;14(4):524-31.

44. Baek YH, Chang E, Kim YJ, Kim BK, Sohn JH, Park DI. Stool methylationspecific polymerase chain reaction assay for the detection of colorectal neoplasia in Korean patients. Dis Colon Rectum. 2009;52(8):1452-9 discussion 9-63.

45. Nagasaka T, Tanaka N, Cullings HM, Sun DS, Sasamoto H, Uchida T, et al. Analysis of fecal DNA methylation to detect gastrointestinal neoplasia. J Natl Cancer Inst. 2009;101(18):1244-58.

46. Chang E, Park DI, Kim YJ, Kim BK, Park JH, Kim HJ, et al. Detection of colorectal neoplasm using promoter methylation of ITGA4, SFRP2, and p16 in stool samples: a preliminary report in Korean patients. Hepatogastroenterology. 2010;57(101):720-7.

47. Tang D, Liu J, Wang DR, Yu HF, Li YK, Zhang JQ. Diagnostic and prognostic value of the methylation status of secreted frizzled-related protein 2 in colorectal cancer. Clin Invest Med. 2011;34(2):E88-95.

48. Zhang H, Song YC, Dang CX. Detection of hypermethylated spastic paraplegia-20 in stool samples of patients with colorectal cancer. Int J Med Sci. 2013;10(3):230-4.

49. Lu H, Huang S, Zhang X, Wang D, Zhang $X$, Yuan $X$, et al. DNA methylation analysis of SFRP2, GATA4/5, NDRG4 and VIM for the detection of colorectal cancer in fecal DNA. Oncol Lett. 2014;8(4):1751-6.

50. Zhang H, Zhu YQ, Wu YQ, Zhang P, Qi J. Detection of promoter hypermethylation of Wnt antagonist genes in fecal samples for diagnosis of early colorectal cancer. World J Gastroenterol. 2014;20(20):6329-35.

51. Niu F, Wen J, Fu X, Li C, Zhao R, Wu S, et al. Stool DNA test of methylated syndecan-2 for the early detection of colorectal neoplasia. Cancer Epidemiol Biomark Prev. 2017;26(9):1411-9.

52. Yang QL, Wang SM, Ma J, Li XW, Liu X, Peng MN, et al. Identification the potential of stool-based SNCA methylation as a candidate biomarker for early colorectal cancer detection. Transl Cancer Res. 2017;6(1):169.

53. Anscombe FJ. On estimating binomial response relations. Biometrika. 1956; 43(3/4):461-4.

54. Haldane JB. The estimation and significance of the logarithm of a ratio of frequencies. Ann Hum Genet. 1956;20(4):309-11.

55. Carozzi FM, Sani CJJoCR. Fecal collection and stabilization methods for improved fecal DNA test for colorectal cancer in a screening setting. 2013; 2013.

56. Pharo HD, Honne H, Vedeld HM, Dahl C, Andresen K, Liestol K, et al. Experimental factors affecting the robustness of DNA methylation analysis. Sci Rep. 2016;6:33936.

57. Mikeska T, Candiloro IL, Dobrovic A. The implications of heterogeneous DNA methylation for the accurate quantification of methylation. Epigenomics. 2010;2(4):561-73.

58. Ushijima T. Detection and interpretation of altered methylation patterns in cancer cells. Nat Rev Cancer. 2005;5(3):223-31.

59. Chang MC, Chiang YC, Ho CM, Chen YL, Chen CA, Cheng WF, et al. New primers for methylation-specific polymerase chain reaction enhance specificity of detecting STAT1 methylation. Taiwan J Obstet Gynecol. 2012; 51(1):43-9.

60. Lan VT, Ha NT, Uyen NQ, Duong NT, Huong NT, Thuan TB, et al. Standardization of the methylation-specific PCR method for analyzing BRCA1 and ER methylation. Mol Med Rep. 2014;9(5):1844-50.

61. Hernández HG, Tse MY, Pang SC, Arboleda H, Forero DA. Optimizing methodologies for PCR-based DNA methylation analysis. Biotechniques. 2013;55(4):181-97.

62. Campan M, Weisenberger DJ, Trinh B, Laird PW. MethyLight. Methods Mol Biol. 2009;507:325-37.

63. Johnson DA, Barclay RL, Mergener K, Weiss G, König T, Beck J, et al. Plasma septin9 versus fecal immunochemical testing for colorectal cancer screening: a prospective multicenter study. PLoS One. 2014;9(6):e98238.

64. Ørntoft MB, Nielsen HJ, Ørntoft TF, Andersen CL. Performance of the colorectal cancer screening marker Sept9 is influenced by age, diabetes and arthritis: a nested case-control study. BMC Cancer. 2015;15:819.

65. Bergheim J, Semaan A, Gevensleben H, Groening S, Knoblich A, Dietrich J, et al. Potential of quantitative SEPT9 and SHOX2 methylation in plasmatic circulating cell-free DNA as auxiliary staging parameter in colorectal cancer: a prospective observational cohort study. Br J Cancer. 2018;118(9):1217-28.

66. Xie L, Jiang X, Li Q, Sun Z, Quan W, Duan Y, et al. Diagnostic value of methylated septing for colorectal cancer detection. Front Oncol. 2018;8:247.
67. Imaoka H, Toiyama Y, Fujikawa H, Hiro J, Saigusa S, Tanaka K, et al. Circulating microRNA-1290 as a novel diagnostic and prognostic biomarker in human colorectal cancer. Ann Oncol. 2016;27(10):1879-86.

68. Duran-Sanchon S, Moreno L, Auge JM, Serra-Burriel M, Cuatrecasas M, Moreira $L$, et al. Identification and validation of microRNA profiles in fecal samples for detection of colorectal cancer. Gastroenterology. 2019.

69. Yau TO, Tang CM, Harriss EK, Dickins B, Polytarchou C. Faecal microRNAs as a non-invasive tool in the diagnosis of colonic adenomas and colorectal cancer: a meta-analysis. Sci Rep. 2019;9(1):9491.

70. Wen J, Xu Q, Yuan Y. Single nucleotide polymorphisms and sporadic colorectal cancer susceptibility: a field synopsis and meta-analysis. Cancer Cell Int. 2018;18:155.

71. Weigl K, Hsu L, Knebel P, Hoffmeister M, Timofeeva M, Farrington S, et al. Head-to-head comparison of family history of colorectal cancer and a genetic risk score for colorectal cancer risk stratification. Clin Transl Gastroenterol. 2019;10(12):e00106.

72. Qian J, Tikk K, Weigl K, Balavarca Y, Brenner H. Fibroblast growth factor 21 as a circulating biomarker at various stages of colorectal carcinogenesis. $\mathrm{Br}$ J Cancer. 2018;119(11):1374-82.

73. Bhardwaj M, Gies A, Weigl K, Tikk K, Benner A, Schrotz-King P, et al. Evaluation and validation of plasma proteins using two different protein detection methods for early detection of colorectal cancer. Cancers (Basel). 2019;11(10)

74. Bhardwaj M, Weigl K, Tikk K, Benner A, Schrotz-King P, Brenner H. Multiplex screening of 275 plasma protein biomarkers to identify a signature for early detection of colorectal cancer. Mol Oncol. 2020;14(1):8-21.

75. McGauran N, Wieseler B, Kreis J, Schuler YB, Kolsch H, Kaiser T. Reporting bias in medical research - a narrative review. Trials. 2010;11:37.

\section{Publisher's Note}

Springer Nature remains neutral with regard to jurisdictional claims in published maps and institutional affiliations.

Ready to submit your research? Choose BMC and benefit from:

- fast, convenient online submission

- thorough peer review by experienced researchers in your field

- rapid publication on acceptance

- support for research data, including large and complex data types

- gold Open Access which fosters wider collaboration and increased citations

- maximum visibility for your research: over $100 \mathrm{M}$ website views per year

At BMC, research is always in progress.

Learn more biomedcentral.com/submissions 